\title{
APLIKASI PEMETAAN DAN DATA TRANSMIGRASI PROVINSI KALIMANTAN SELATAN
}

\author{
Fakultas Teknologi Informasi \\ Universitas Islam Kalimantan Muhammad Arsyad Al Banjari Banjarmasin \\ Hendra Sanjaya \\ Hendrasanjaya25@gmail.com
}

\begin{abstract}
ABSTRAK
Kebutuhan akan pengolahan data atau informasi sangat terasa disaat pengelolaan perusahaan dihadapkan pada situasi yang penuh persaingan serta mendesak untuk memutuskan suatu kebijakan, tetap mampu berjalan sesuai dengan rencana dan semua informasi yang berkaitan dengan pengelolaan perusahaan tersebut harus bisa disajikan tepat pada waktunya. Dinas Tenaga Kerja dan Transmigrasi (Disnakertrans) Banjarmasin merupakan salah satu instansi pemerintahan yang melaksanakan urusan pemerintah daerah atau kewenangan provinsi, di bidang kesekretarian, pembinaan dan penempatan tenaga kerja, hubungan industrial, perlindungan dan ketenagakerjaan dan ketransmigrasian serta tugas pembantuan. Salah satu pekerjaan pada disnakertrans juga ada bidang yang menangani pemetaan batas wilayah keberadaan transmigran, disana proses pemetaan dilakukan masih belum terkomputerisasi yang mana pengerjaannya masih secara manual atau menggunakan peta peta yang cetak. Pengerjaan tersebut memerlukan waktu yang cukup lama dan hasil pemetaan tersebut juga sangat terbatas karena masyarakat luas tidak bisa mendpatkan informasi lengkap dan mudah tentang ke batas wilayah transmigrasi disekitar wilayah Kalimantan Selatan. Sesuai dengan kebutuhan guna memudahkan pengguna mendapatkan Sitem Informasi data transmigran. Maka aplikasi yang akan di buat khusus menangani tentang data daerah transmigran beserta peta wilayahnya, dengan adanya program ini diharapkan akan bisa di jadikan acuan untuk Mengetahui batas-batas wilayah transmigrasi.
\end{abstract}

Kata Kunci : Aplikasi, Pemetaan, Transmigran

\section{LATAR BELAKANG}

Perkembangan teknologi yang berkembang pesat tersebut, arus informasi kiranya dapat disampaikan dengan cara yang cepat dan tepat. Untuk memenuhi hal tersebut, maka perusahaan pembuat software pun berusaha untuk membuat paket - paket yang sesuai dengan kebutuhan zaman yaitu untuk memberikan informasi dengan cepat, tepat dan akurat serta yang dilakukan dengan manual mulai berubah menjadi cara yang lebih terotomatis dengan bantuan aplikasi komputer. Kebutuhan akan pengolahan data atau informasi sangat terasa disaat pengelolaan perusahaan dihadapkan pada situasi yang penuh persaingan serta mendesak untuk memutuskan suatu kebijakan, tetap mampu berjalan sesuai dengan rencana dan semua informasi yang berkaitan dengan pengelolaan perusahaan tersebut 
harus bisa disajikan tepat pada waktunya.

Program Aplikasi dan Sistem Informasi Merupakan salah satu program yang banyak digunakan oleh banyak instansi atau perusahaan dalam era globalisasi sekarang ini, baik itu instansi pemerintah maupun swasta seperti perusahaan-perusahaan besar dalam menjalankan aktivitas sehari-hari yang berhubungan dengan penyajian data secara cepat dan akurat. Pada Dinas Tenaga Kerja dan Transmigrasi (Disnakertrans) Banjarmasin merupakan salah satu instansi pemerintahan yang melaksanakan urusan pemerintah daerah atau kewenangan provinsi, di bidang kesekretarian, pembinaan dan penempatan tenaga kerja, hubungan industrial, perlindungan dan ketenagakerjaan dan ketransmigrasian serta tugas pembantuan. Salah satu pekerjaan pada disnakertrans juga ada bidang yang menangani pemetaan batas wilayah keberadaan transmigran, disana proses pemetaan dilakukan masih belum terkomputerisasi yang mana pengerjaannya masih secara manual atau menggunakan peta peta yang cetak yang ada dipasaran. Pengerjaan tersebut memerlukan waktu yang cukup lama dan hasil pemetaan tersebut juga sangat terbatas karena masyarakat luas tidak bisa mendpatkan informasi lengkap dan mudah tentang ke batas wilayah transmigrasi disekitar wilayah Kalimantan Selatan.

Melalui penelitian ini, peneliti membuat suatu aplikasi yang berhubungan dengan sistem informasi pemetaan batas wilayah, aplikasi yang akan di buat khusus menangani tentang data daerah transmigran beserta peta wilayahnya, sesuai dengan kebutuhan guna memudahkan pengguna mendapatkan Sitem Informasi data transmigran. Dengan adanya program ini diharapkan akan bisa di jadikan acuan untuk mengetahui batas-batas wilayah transmigrasi secara spesifikasi, dapat mengamati peta yang terdapat dalam aplikasi ini serta mengetahui banyaknya transmigran beserta data-data dirinya.

\section{RUMUSAN MASALAH}

Merancang dan membuat suatu aplikasi sistem informasi pemetaan batas wilayah serta data transmigrasi. yang akan membantu dan dapat memudahkan dalam akses sistem informasi mengenai batas wilayah serta data transmigran yang ada di wilayah Kalimantan Selatan.

\section{TUJUAN PENELITIAN}

Penelitian ini bertujuan untuk membuat aplikasi sistem informasi pemetaan batas wilayah serta data transmigrasi di wilayah Kalimantan Selatan.

\section{MANFAAT PENELITIAN}

Manfaat yang di peroleh dari penelitian pembuatan aplikasi ini ialah ;

1. Memudahkan petugas staf administrasi disnakertrans bidang P4trans untuk mengetahui data transmigran yang ada dikawasan Kalimantan Selatan

2. Memudahkan dalam pencarian data transmigran.

3. Memudahkan dalam pencarian lokasi transmigran.

4. Memudahkan petugas staf administrasi dalam membuat laporan

\section{LANGKAH LANGKAH PERANCANGAN SISTEM}


Langkah yang digunakan dalam penelitian ini adalah merancang dan membuat program Aplikasi Sistem Informasi Pemetaan Wilayah dan Data Transmigran, dengan langkah-langkah sebagai berikut :

1) Mempersiapkan alat dan bahan yang diperlukan

2) Membuat rancangan basis data (database) Sistem Informasi Data Pemetaan

3) Membuat diagram tentang Data Transmigran

4) Menerjemahkan diagram alir program ke dalam bahasa pemrograman Delphi

5) Membuat program basis data Sistem Informasi Data Pemetaan pada Delphi

6) Mengkompilasi program

7) Melakukan pengujian program

8) Melakukan revisi atau perbaikan program apabila diperlukan.

Metode penelitian dalam hal ini meliputi perancangan yang kemudian diwujudkan dengan menggunakan Software Delphi 2010 .

\section{ANALISA KEBUTUHAN SISTEM}

Dalam desain Aplikasi Pemetaan dan Data Transmigran yang akan dibuat nanti diharapkan dapat menyelesaikan masalah-masalah yang dihadapi dalam hal pencarian batas wilayah transmigran di kawasan Kalimantan Selatan. Menu yang akan di buat diantaranya adalah :

1) Menu Input Pemetaan Batas Wilayah Transmigran.

2) Menu Input Pegawai Disnakertrans khususnya P4Trans

3) Menu Input Admin P4Trans.

4) Menambahkan Informasi tentang Disnakertrans

ANALISA KEBUTUHAN INFORMASI

Jurnal Ilmiah "Technologia"
Hasil yang dapat diperoleh dengan adanya Aplikasi Pemetaan dan Data Transmigran ini berupa kemudahan dalam pengolahan data dan menampilkan informasi yang diperlukan (Output). Sehingga kebutuhan akan sistem informasi ini menjadi lebih lengkap dan pelayanan terhadap masyarakat akan lebih memuaskan.

\section{CONTEXT DIAGRAM}

Diagram ini merupakan gambaran umum sistem yang dibuat. Secara uraian dapat dikatakan bahwa diagram konteks itu berisi siapa saja yang memberikan data (inputan) kesistem serta kepada siapa data informasi yang harus dihasilkan sistem.
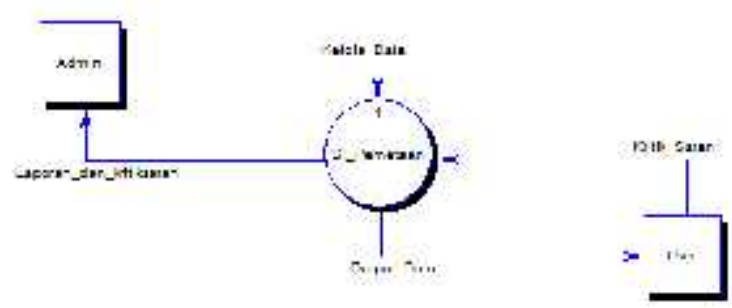

DATA FLOW DIAGRAM

Data Flow Diagram menunjukan data yang mengalir dari satu entity ke entity lain yang dikembangkan secara logika tanpa mempertimbangkan lingkungan fisik data mengalir atau lingkungan fisik dimana data disimpan.

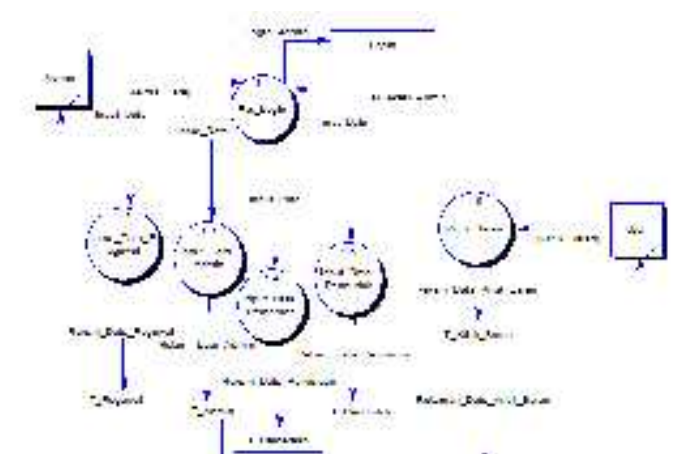




\section{TAMPILAN APLIKASI}
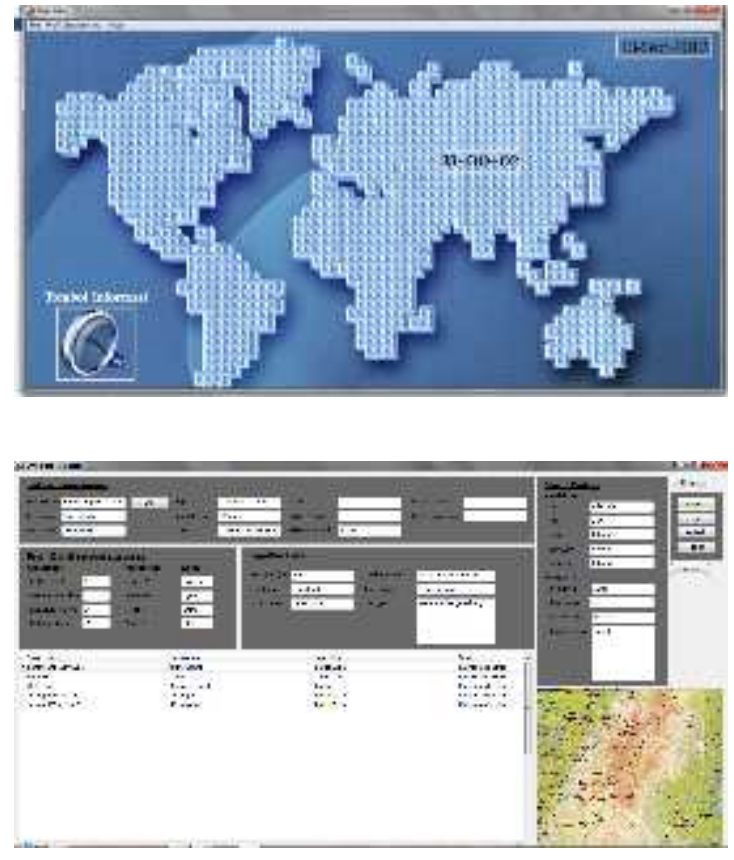

HASIL OUTPUT APLIKASI

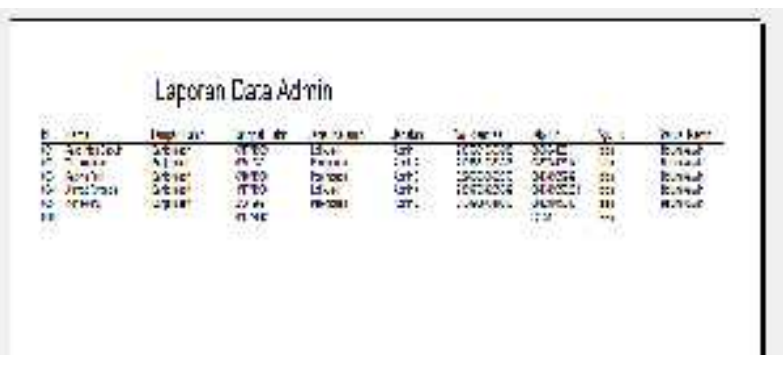

\section{KESIMPULAN}

Berdasarkan hasil dari penelitian dan pembahasan yang telah dikemukakan, dapat ditarik kesimpulan, yaitu :

1. Aplikasi Pemetaan dan Data Transmigran yang diusulkan dapat memberikan informasi kepada masyarakat atau dinas lain tentang peta batas wilayah transmigrasi di daerah Kalimantan Selatan

2. Aplikasi Pemetaan dan Data Transmigran yang diusulkan dapat memberikan informasi kepada masyarakat atau dinas lain tentang informasi pegawai dan admin di disnakertrans Banjarmasin.

3. Palikasi Sistem Informasi yang diusulkan dapat memberikan informasi kepada masyarakat atau dinas lain tentang profil,visi dan misi disnakertrans Banjarmasin.

\section{SARAN}

Adapun saran-saran yang diusulkan setelah membuat aplikasi sistem informasi yang diusulkan adalah sebagai berikut:

a. Dengan adanya sistem informasi ini bisa memberikan informasi kepada masyarakat atau dinas lain tentang peta batas wilayah transmigrasi di daerah Kalimantan Selatan se efesien dan se efektif mungkin sehingga memudahkan masyarakat atau dinas lain untuk mengakses atau mencari data tentang perpindahan penduduk di Disnakertrans Banjarmasin.

b. Dengan adanya sistem informasi ini bisa memberikan informasi kepada masyarakat atau dinas lain tentang data pegawai dan admin yang ada di Disnakertrans Banjarmasin terutama di bidang P4Trans.

c. Dengan adanya sistem informasi ini bisa memberikan informasi kepada masyarakat atau dinas lain tentang profil,visi dan misi yang dimiliki 
oleh Dinas Tenaga Kerja Dan Transmigrasi Banjarmasin.

d. Aplikasi Pemetaan dan Data Transmigran ini memiliki kekurangan dan kelebihan masingmasing dari sistem informasi yang sudah ada. Dikarenakan program ini masih memiliki kekurangan maka kiranya dapat memakluminya.

e. Bagi peneliti selanjutnya diharapkan agar dapat menggali lebih dalam tentang informasi batas wilayah transmigrasi khususnya di daerah Kalimantan Selatan.

\section{DAFTAR PUSTAKA}

[1] Andi, 2010, Delphi 2010 Programming Konsep dan Implementasi, Wahan Kencana, Yogyakarta

[2] Jogiyanto HM., 1999, Analisis dan Disain Informasi: Pendekatan Terstruktur Teori dan Praktek Aplikasi Bisnis, Andi Offset, Yogyakarta

[3] Kroenke, D.M., 2005, Database Processing: Dasar-Dasar, Desain dan Implementasi. Erlangga. Jakarta.
[4] Sidharta, Lani, 1995, Pengantar Sistem Informasi Bisnis, P.T. ELEX Media Komputindo, Jakarta

[5] Mulyadi, 2001, Akuntansi Manajemen Konsep,Manfaat dan rekayasa edisi ketiga, Salemba empat, Jakarta

[6] Neuschel, Richard F, 1960, Management by System, McGrawHill, New York.

[7] Http://bto.depnakertrans.go.id/kad/k awasan.php diakses 9 Juni 2015

[8] Http://disnakertrans.kalselprov.go.id diakses 10 Juni 205

[9] Http://itcreativebjm.wordpress.com / 2010 / 11 / 28 /menghubungkandelphi-2009-dengan-database-mysql diakses 10 Juni 2015 